\title{
Unfair terms in commercial contracts and the two laws of competition:
}

\section{French law and English law contrasted}

\section{Simon Whittaker*}

It is widely recognised that there is an important relationship between contract law in the traditional sense of the law governing the relative rights and duties of parties arising from the conclusion, performance or non-performance of a contract and the wider regulation of the environment (and typically the markets) in which contracts are made and performed. ${ }^{1}$ An obvious example is found in the case of consumer contracts, where legislative protections attract enforcement measures by public authorities as well as providing consumers with rights of redress of various types against the traders with whom they have dealt. ${ }^{2}$ There are also direct links between contract law and competition law (perhaps the archetypical example of the regulation of markets) in that anti-competitive agreements (such as a price-fixing agreements between two undertakings or contract terms "in unreasonable restraint of trade") are (subject to various conditions) illegal contracts or contract terms and therefore unenforceable. ${ }^{3}$

In this article, however, I wish to explore a less obvious aspect of the relationship between contract law and competition law, focusing on contrasting controls on the

\footnotetext{
*Professor of European Comparative Law, University of Oxford and Fellow of St John's College, Oxford; simon.whittaker@law.ox.ac.uk. The author is grateful to the anonymous reviewers for their comments. ${ }^{1}$ Hugh Collins, Regulating Contracts (OUP, Oxford, 1999).

${ }^{2}$ Eg as regards unfair contract terms see the Consumer Rights Act 2015 ss $62 \& 70$ and Sch 3 and as regards unfair commercial practices see the Consumer Protection from Unfair Protection from Unfair Trading Regulations 2008, SI 2008/1277, esp Pt 4A (as amended in 2014).

${ }^{3}$ Hugh Beale (gen ed) Chitty on Contracts ( $33^{\text {rd }}$ edn, 2018) paras 16-106 et seq. (D.D.Prentice).
} 
effectiveness of the terms of contracts between traders ${ }^{4}$ in English law and in French law.

Over the past decade, French law has created two new legislative controls on contract terms modelled on the test of unfairness in its Consumer Code which implements the European directive $e^{5}$ but applicable outside the consumer context. The first of these originated in the regulation of the market practices of large-scale retailers in relation to their suppliers and was inserted in the Commercial Code in 2008 as part of the law of unfair competition, but it is generally seen as applicable to all "commercial contracts". 6 The second control was inserted into the Civil Code as part of wider reform of the law of contract and obligations in $2016,^{7}$ applicable to contrats d'adhésion (broadly, standard form contracts). ${ }^{8}$

At first sight, this French position could not contrast more strikingly with English law, which possesses a general scheme of control of the fairness of contract terms only as regards consumer contracts, and whose particular controls beyond this concern mainly exemption clauses and penalty clauses. ${ }^{9}$ However, the UK has addressed concerns about the commercial practices of large grocery retailers in relation to their suppliers apparently similar to those which led to the French controls on commercial contracts, but it did so as a matter of competition law after market investigation and by means of a dedicated code of conduct and statutory regulator. ${ }^{10}$ This contrast of approach is particularly topical given the European

\footnotetext{
${ }^{4}$ In the following, "traders" refers to persons acting in the course of a business, trade or profession. In the English context, a contract between traders would often simply be called a commercial contract, but in French law "commercial contracts" (les contrats commerciaux) has a technical significance: see below, p 00.

${ }^{5}$ Arts L 212-1 - 212-3; R 212-1 - 212-5 Code de la consommation (C consom); Directive 1993/13/EC on unfair terms in consumer contracts [1993] OJ L95/29 (1993 Directive).

${ }^{6}$ Art 442-6.I. $2^{\circ}$ Code de commerce (C com) and see below, p 00.

${ }^{7}$ Ordonnance no 2016-131 of 10 February 2016 portant réforme du droit des contrats, du régime général et de la preuve des obligations (2016 Ordonnance) as amended by loi no 2018-287 of 20 April 2018 ratifiant l'ordonnance no 2016-131 du 10 février 2016 portant réforme du droit des contrats, du régime général et de la preuve des obligations (2018 loi de ratification). On the 2016 reform, see generally John Cartwright and Simon Whittaker (eds) The Code Napoléon Rewritten, French Contract Law after the 2016 Reforms (2017).

${ }^{8}$ Arts 1110 and 1171 Code civil (C civ) (2016 and then amended in 2018) and see below, p 00. Where provisions of the French Civil Code have been subject to reform or amendment, the version in question will be designated by the date of its coming into force.

${ }^{9}$ Below, p 00.

${ }^{10}$ Below, p 00.
} 
Commission's recent proposal for a directive to regulate unfair commercial practices in the food supply chain. ${ }^{11}$

Before explaining the two national laws, I need first to note two possible senses of "competition law". In the sense usual in the UK, competition law refers to a body of rules which seeks to ensure that competition is free, primarily in the interests of consumers. ${ }^{12}$ In UK law, these rules set out broad controls (modelled on EU law) on anti-competitive agreements or concerted actions and on the abuse of a dominant position in the market, and they also provide a series of public powers to intervene in particular markets after an investigation has found evidence of market failure. ${ }^{13}$ French law also contains a body of law concerned with free competition, partly modelled on EU law but with its own particular national features ${ }^{14}$ contained in the Commercial Code under the heading of 'anti-competitive practices' (les pratiques anticoncurrentielles). ${ }^{15}$

In a second sense, however, "competition law" can refer to a body of law which seeks to ensure that competition is fair in the interests of other traders rather than, or at least as much as, of consumers. Very broadly, the idea is that improper market behaviour by a trader (whether to other traders or to consumers) allows that trader an unfair competitive advantage in the market vis-à-vis other traders. In common with other continental laws, ${ }^{16}$ French law has long possessed such a general law of unfair competition (le droit de la concurrence déloyale) developed first by the courts under the law of extra-contractual liability for fault in

\footnotetext{
${ }^{11}$ Proposal for a Directive of the European Parliament and of the Council on unfair trading practices in business-to-business relationships in the food supply chain COM(2018) 173 final.

${ }^{12}$ Richard Whish and David Bailey, Competition Law $\left(9^{\text {th }}\right.$ edn, 2018) $18-23$.

${ }^{13}$ Ibid, Ch 2, explaining the relationship between EU and UK law. On market investigations, see below, p 00.

${ }^{14} \mathrm{Eg}$ the prohibition of "the unfair exploitation by a trader of another trader's state of economic dependence where this is susceptible to affect the functioning or the structure of competition": art L 420-2(2) C com.

${ }^{15}$ Arts L 420-1 - 420-7 C com.

${ }^{16}$ On unfair competition generally, see F. Henning-Bodewig (ed) International Handbook of Unfair Competition Law (Richard Hart, Oxford, 2013) which contains national overviews.
} 
the Civil Code ${ }^{17}$ but later developed by specific rules in the Commercial Code under the heading les pratiques restrictives de concurrence. ${ }^{18}$ By contrast, apart from legislation governing unfair commercial practises business-to-consumer (which implements a EU directive and which is generally seen in the UK as concerned with the protection of consumers, even though the directive is concerned "indirectly" with the protection of the interests of competitor traders ${ }^{19}$ ), neither the English common law nor statute have recognised a general legal prohibition of (or ground of liability for) unfair practices trader-totrader since, as Lord Devlin put it, for the common lawyer "free dealing was fair dealing.",20 There is therefore no general domestic English law of unfair competition, even though there are torts (such as passing off or which sanction the infringement of intellectual property) which govern situations typically attracting unfair competition law on continental Europe. ${ }^{21}$

What, then, is the background to the modern French law governing unfair terms contracts between traders?

\section{The French background: principle and counter-principle}

The Civil Code as enacted in 1804 defined a "contract" as an agreement by which a person undertakes obligations "to give, to do or not to do" 22 without any restriction as to subject-

\footnotetext{
${ }^{17}$ Arts $1382-1383 \mathrm{C}$ civ (1804), now arts $1240-1241 \mathrm{C}$ civ (2016).

18 Book IV Title IV C com.

${ }^{19}$ Directive 2005/29/EC concerning unfair business-to-consumer commercial practices [2005] OJ L149/22 (Unfair Commercial Practices Directive) recital 8. Art 11 requires means of enforcement of its prohibitions for "persons or organisations regarded under national law as having a legitimate interest in combating unfair commercial practices, including competitors."

${ }^{20}$ Lord Devlin, The Enforcement of Morals (OUP, Oxford, 1965) 47 (emphasis added).

${ }^{21}$ See below, $\mathrm{p} 00$.

${ }^{22}$ Translations from the French are the author's with the exception of the new provisions of the Civil Code (below, p 00) which are by Bénédicte Fauvarque-Cosson, John Cartwright and the author: http://www.textes.justice.gouv.fr/art_pix/THE-LAW-OF-CONTRACT-2-5-16.pdf.
} 
matter or requirement of formality and provided that, once lawfully concluded, the contract binds the parties. ${ }^{23}$ Contracting parties were seen as fundamentally equal ${ }^{24}$ and this led to a restrictive approach to invalidity on the ground of public policy (ordre public) or public morality (bonnes moeurs), ${ }^{25}$ to the rejection of invalidity on the ground of substantive imbalance in the contract (lésion), ${ }^{26}$ and to the explicit recognition of the binding character of penalty clauses. ${ }^{27}$ In the nineteenth century this approach found support in the idea that contracts were an expression of the "autonomy of the will" of the parties ${ }^{28}$ and that on this ground they were fair: as Fouillé's well-known aphorism put it, "qui dit contractuel, dit juste." 29

However, this picture changed considerably over the twentieth century.

First, according to Raymond Saleilles, the lack of any real choice in the party "agreeing" to a block of terms imposed by another party in what he called contrats d'adhésion (under which one party unilaterally sets the terms and the other merely "adheres" to them) means that they are more akin to administrative regulations than contracts ${ }^{30}$ and while his conclusion was not itself adopted by courts or most writers, ${ }^{31}$ Saleilles' analysis led to a widespread sense that standard form contracts could not be justified by reference to established contractual principle.

\footnotetext{
${ }^{23}$ Arts 1101 \& 1134(1) C civ (1804).

${ }^{24}$ See, eg, Jean-Etienne-Marie Portalis, 'Discours préliminaire sur le projet de Code Civil' in Frédéric Portalis (ed) Discours, rapports et travaux inédits sur le Code civil par Jean-Etienne-Marie Portalis (Joubert, Paris, 1844) reprinted by Centre de Philosophie polique et juridique (Université de Caen, 1990), 54.

${ }^{25}$ See arts 6, 1108, 1128, 1131 and $1133 \mathrm{C}$ civ (1804).

${ }^{26} \mathrm{Art} 1118 \mathrm{C}$ civ (1804), though exceptions were foreseen as regards certain types of contract.

${ }^{27}$ Art.1152 C civ (1804); penalty clauses were defined in art $1226 \mathrm{C}$ civ (1804).

${ }^{28}$ Véronique Ranouil, L'autonomie de la volonté, Naissance et evolution d'un concept (PUF, Paris, 1980).

${ }^{29}$ In fact, Alfred Fouillée, a social anthropologist, argued that contracts are a form of fraternal relationship regulated by justice: La science sociale contemporaine (Paris, Hachette, $2^{\text {nd }}$ edn, 1885 used) 410 and see Louise Rolland, ' "Qui dit contractuel, dit juste' (Fouillée) - en trois petits bonds, à reculons' (2006) 51 McGill LJ 765. ${ }^{30}$ Raymond Saleilles, De la declaration de volonté, Contribution à l'étude de l'acte juridique dans le Code civil allemande (Pichon, Paris, 1901) 229 - 230 and see François Chénedé 'Raymond Saleilles, Le contrat d'adhésion (part 1) (2012) Revue des contrats 241 \& (part 2) 1017 for an extended discussion.

${ }^{31}$ Chénedé, n 30, Pt 2, 1020 - 1021.
} 
Secondly, French writers and courts became increasingly hostile to exemption clauses and, later, penalty clauses. A number of techniques were used to control exemption clauses, some direct and based on ordre public ${ }^{32}$ and some decidedly more circuitous. ${ }^{33}$ In the case of penalty clauses, in 1975 the Civil Code was amended so as to allow a court to reduce or increase the sum agreed where it was "manifestly excessive or derisory" ${ }^{34}$ In both cases, these controls applied in principle to all types of contract and whatever the character of the contracting parties (trader, consumer or neither).

Thirdly, in the course of the twentieth century the French legislature created a series of important bodies of law regulating particular types of contract (notably, insurance contracts, various types of leases and contracts of employment) many or all of whose rules are mandatory in the sense that they are not subject to exclusion or modification by the agreement of the parties in a way which reduces the rights of the protected person (insured person, lessee or employee). ${ }^{35}$

Finally, from the 1980s, some French jurists argued that good faith (which was required by the Civil Code in the performance of contracts ${ }^{36}$ ) had very broad implications for the development of substantive law. This found a number of concrete expressions, providing a legal basis for the imposition of liability for the abrupt breaking-off of negotiations, precontractual obligations of information, contractual obligations of co-operation and 'loyalty'

\footnotetext{
${ }^{32}$ Notably, it is contrary to public policy to seek to exclude one's liability for $d o l$ (dishonest conduct including deliberate contractual non-performance) or faute lourde (gross fault): eg Com 15 juin 1959, D 1960.97 note René Rodière.

${ }^{33}$ Notably, a business seller was held unable to exclude its liability for defects in property sold on the basis that he was presumed to know of them: art 1643 C civ and see Civ (1) 24 novembre 1954, JCP 1955.II.8565 note H.B. A party to a contract was held unable to exclude liability for breach of its own "essential obligation" on the basis of the doctrine of la cause: Com 22 juin 1996, affaire Chronoposte, D 1997.121 note Sériaux; Com 29 juin 2010, Sociéte Faurecia, JCP G 2010.787.

${ }_{34}$ Art 1152(1) C civ (1804 to 2016); similar provision is now made by art 1231-5 C civ (2016).

${ }^{35}$ As regards the Code des assurances (first codified in 1976) see now art 111-2. The regulatory regimes governing leases are d'ordre public for the protection of lessees whether they concern residential, commercial or agricultural leases: Alain Bénabent, Droit civil, Les contrats spéciaux civils et commerciaux (Montchrestien, $7^{\text {th }}$ edn, 2001) 284.

${ }^{36}$ Art 1134 al 3 C civ (1804).
} 
and controls on the exercise of some contractual rights. ${ }^{37}$ Indeed, some jurists saw good faith as reflecting the law's proper concern with contractual justice or fairness, itself reflecting a wider French model of "social solidarity". ${ }^{38}$ In this way, the principle of good faith can be seen as a counter-principle to the classic principles of freedom of contract and the binding force of contracts. ${ }^{39}$ Moreover, there can be a close relationship between good faith and the broader French doctrinal theory of the abuse of rights. So, while French courts did not see good faith as requiring them to assess the fairness of contract terms, the first legislative controls on the terms of consumer contracts combined ideas of the abuse of the trader's right to contract (hence, clauses abusives) and of the need to correct the "excessive advantage" which may result. ${ }^{40}$

How, though, did these civil law developments relate to contemporary changes in the French regulation of the market and to competition law?

By the Décret d'Allarde of 1791 the revolutionary legislator swept away the special "privileges" of trade corporations and the wider economic regulation of the ancien régime and established what became known as the principle of freedom of industry and commerce and, therefore, of competition. ${ }^{41}$ This principle dominated the approach of French lawyers to the market throughout the nineteenth century, but its "excesses" were seen as needing "correction" and the basis of this was found in the idea that where competition was unfair it could constitute delictual fault under the Civil Code. ${ }^{42}$ Judicial decisions on "fault" therefore

\footnotetext{
${ }^{37}$ François Terré, Philippe Simler and Yves Lequette, Droit civil, Les obligations (Dalloz, 11 ${ }^{\text {th }}$ ed., 2013 ) 201 204, 284 and 486 - 492 respectively.

${ }^{38}$ See esp Denis Mazeaud, 'Loyauté, solidarité, fraternité: la nouvelle devise contractuelle? in L'avenir du droit, Mélanges Terré (Paris, Dalloz, 1999) 603.

${ }^{39}$ Simon Whittaker 'Contracts, Contract Law and Contractual Principle' in Cartwright and Whittaker n 7, ch 2.

${ }^{40}$ Loi no 78-23 of 10 janvier 1978 sur la protection et l'information des consommateurs de produits et de services art 35(1) (authorising the administration to prohibit unfair terms in consumer contracts).

${ }^{41}$ Loi des 2 \& 17 mars 1791 'Décret d'Allarde'; Antoine Pirovano, 'L'évolution de l'action en concurrence déloyale en droit francais' in Mélanges Bernard Dutoit (Droz, Geneva, 2002) 467 at $467-468$.

${ }^{42}$ Traité de droit commercial Georges Ripert/René Roublot, Tome 1, Vol 1 (18 ${ }^{\text {th }}$ edn by Louis Vogel) (LDGJ, Paris, 2001) 590 - 591.
} 
reflected the courts' sense of what constituted improper commercial behaviour from the point of view of competitors, ${ }^{43}$ but this was supplemented by particular legislative rules prohibiting certain trade practices (for example in relation to the adulteration of food or other fraudulent trade practices) in the interests of other traders rather than of consumers. ${ }^{44}$ As a result, a trader who acted "unfairly" in furtherance of its business was liable in damages to any other trader suffering loss as a result and could be ordered by a court to cease the relevant activity. ${ }^{45}$ Moreover, the purpose of the law of unfair competition was reflected in the fact that only competing traders or trade associations could sue. ${ }^{46}$ When, therefore, legislation began to be passed in the 1970s against unfair practices by traders overtly to protect consumers, it was seen as belonging to "consumer law" (le droit de la consommation) and was primarily enforced by criminal offences ${ }^{47}$ whereas the law of unfair competition remained part of the civil law of delictual liability. This distinctiveness of consumer law was emphasised by its codification in the Consumer Code in $1993,{ }^{48}$ while legislation governing unfair competition law was codification in the Commercial Code. ${ }^{49}$

Secondly, after the Second World War many goods and services were subject to direct price controls imposed by administrative decree ${ }^{50}$ despite the principle of liberty of commerce and even though at the time civil law writers retained the "autonomy of the will" and freedom of contract as principles of private contract law. ${ }^{51}$ While legislation in support of freedom of competition by subjecting anti-competitive agreements (ententes) to criminal

\footnotetext{
${ }^{43}$ Ibid, 601 et seq.

${ }^{44}$ Luc Bihl, Le droit penal de la consommation (Nathan, Paris, 1989) 7 - 8.

${ }^{45}$ Pirovano, n 41, $489-90$.

${ }^{46}$ Ibid, $499-500$.

${ }^{47}$ Bihl, no 44, 8 .

${ }^{48}$ Jean Calais-Auloy \& Henri Temple, Droit de la consommation (Dalloz, $8^{\text {th }}$ edn, Paris, 2010) $36-37$.

${ }^{49}$ Below, p 00.

${ }^{50}$ John Sheahan, 'Problems and Possibilities of Industrial Price Control: Postwar French experience' (1961) 51 The American Economic Review 345, noting that the legislation dated from pre-war socialist government of 1936.

${ }^{51}$ Jean Carbonnier, Droit civil, 4. Les obligations (PUF, Paris, $14^{\text {th }}$ edn, 1990) $45-47$ seeing the value of the "autonomy of the will" as a principle even in an age of the "socialisation" of droit civil.
} 
sanctions was enacted in the $1950 \mathrm{~s},{ }^{52}$ it was not until 1986 that the laws on price controls and on free competition were reformed as part of a wider liberalisation of the French economy. ${ }^{53}$ The new law of 1986 roundly declared that "the prices of property, products and services ... are freely determined by the play of competition, ${ }^{, 54}$ it prohibited anti-competitive agreements and the abuse of a dominant market position in a way modelled closely on the parallel EU competition provisions and it also prohibited the "abuse of a situation of dependence" 55 where it has as its aim or effect the prevention, restraint or distortion of the play of competition on the market ${ }^{56}$ and "discrimination" between customers as regards prices or terms and conditions. ${ }^{57}$ These provisions form the background to art 442-6-I. $2^{\circ}$ of the Commercial Code which provides for the review of the fairness of the terms of "commercial contracts" even where they set prices.

\section{Unfair competitive practices and unfair contract terms in the French}

\section{Commercial Code}

Article 442-6-I. $2^{\circ}$ forms part of a complex series of provisions governing "Transparency, practices restrictive of competition, and other prohibited practices" (Title IV) which belong to

\footnotetext{
${ }^{52}$ Notably, décret no 53-704 du 9 août 1953 relatif au maintien ou au rétablissement de la libre concurrence industrielle et commerciale.

${ }^{53}$ Ordonnance no 86-1243 du ler décembre 1986 relative à la liberté des prix et de la concurrence (1986 Ordonnance).

${ }^{54} 1986$ Ordonnance, art 1(1). The Ordonnance is codified in art 410-2 et seq C com.

551986 Ordonnance art 8-2.

${ }^{56}$ Art 8-2(1) referring to "the same conditions" ie as are stated in art 7(1) which concerns anti-competitive agreements or concerted action.

${ }^{57} 1986$ Ordonnance art 36.
} 
a wider treatment of freedom of prices and competition (Book IV). As enacted in 2008 (and as presently in force ${ }^{58}$ ), it provides that:

I. The following behaviour by any producer, merchant [commerçant], manufacturer, or person registered on the register of trades attracts responsibility in its perpetrator and obliges him to make reparation for the loss caused by this action: $1^{\mathrm{o}} \ldots$

$2^{\circ}$ Subjecting or attempting to subject a commercial partner to obligations creating a significant imbalance in the rights and obligations of the parties;

Unlike Title II of Book IV (which prohibits, for example, anti-competitive agreements, ${ }^{59}$ and whose purpose is to ensure that the conduct of undertakings contributes to the well-being of consumers by leading to lower prices, better quality goods and services, and wider choice ${ }^{60}$ ), Title IV is principally concerned to "guarantee, in the name of economic public policy, the transparency (Chapter I) and the fairness of commercial relations between suppliers and their customers, notably in the retail sector (Chapter II), without any real consideration of the possible effects on competition of the practices with which it is concerned."61 In short, Title IV concerns fairness of competition while Title II concerns freedom of competition.

The background to art 442-6.I. $2^{\circ}$ was legislation in 1958 prohibiting "price discrimination" by sellers of goods or suppliers of services as between their customers, ie charging different customers different prices or contracting with them on different terms. ${ }^{62}$ The original purpose was to protect small retailers of goods from their own suppliers' use of

\footnotetext{
${ }^{58}$ Loi no 2008-776 du 4 août 2008 de modernisation de l'économie (2008 loi) art 93. Later amendments concern only art L 442-6.IV's provisions on consultation.

${ }^{59}$ However, the market abuses which art L 422-6 C com sets out are designated as ways by which the condition of l'exploitation abusive may be satisfied for the purposes of the anti-competitive practice of the abuse of a state of economic dependency prohibited by art 420-2(2) C com.

${ }^{60}$ Marie-Dominique Hagelsteen, La négociabilité des tariffs et des conditions générales de vente, Rapport de Marie-Dominique Hagelsteen (12 February 2008) (Hagelsteen Report) para 2.1.1. This report was commissioned by the French government and its recommendations led to the 2008 loi, below, p 00.

${ }^{61}$ Hagelsteen Report, para 2.1.1.

${ }^{62}$ Décret no. 58-545 du 24 juin 1958 modifiant certaines dispositions de l'ordonnance no. 45-1483 du 30 juin 1945 relative au maintien de la libre concurrence art. 1 .
} 
their bargaining power to negotiate differential prices, ${ }^{63}$ but when the relative bargaining power of suppliers and retailers was largely reversed in the 1970s as a result of the rise of supermarket chains, the scope of the prohibition was nevertheless extended. ${ }^{64}$ As earlier noted, this prohibition survived the general liberalisation of prices in 1986, though its sanction was reduced from a criminal penalty to the imposition of civil liability and the possibility of an injunction, the new law providing that "any producer, merchant, industrial operator or artisan" is liable for a practice "as regards his economic partner, of obtaining from him prices, delays for payment, conditions of sale or other modalities of sale or purchase which are discriminatory and not justified by any genuine counterpart by creating from this action for the partner, a competitive disadvantage or advantage." ${ }^{, 65}$ Sellers had an obligation to communicate their "general conditions of sale" (conditions générales de vente or CGV), including their tariff of prices per unit together with any discounts and conditions regarding payment to all their would-be customers ${ }^{66}$ and it was "discrimination" to deviate from them. ${ }^{67}$ Since in practice it was difficult to justify "discrimination" it was seen as useless to negotiate tariffs or general conditions of sale. ${ }^{68}$

Title IV of the Code also prohibited resale at a loss, that is to say, sales by a retailer to a customer at a price lower than the "effective price" paid by the retailer to its own supplier. ${ }^{69}$ This prohibition was intended to protect small local retailers by preventing their suppliers (for example, a manufacturer or large food producer) from fixing their prices at an extremely low

\footnotetext{
${ }^{63}$ Rapport by Jean-Paul Charié, député, on behalf of the Commission des affaires économiques, de l'environnement et du territoire sur le projet de loi de modernisation de l'économie of the Assemblé nationale (22 mai 2008) Ass Nat no 908 (Charié Report (2008)) 284.

${ }^{64}$ Charié Report (2008), 285.

651986 Ordonnance art 36(1) codified as art 442-6 C com.

${ }^{66} 1986$ Ordonnance art 33 codified as art L 441-6.I C com, though much amended.

${ }^{67}$ While an attempt was made in 2005 to allow a seller or supplier to "discriminate" between its customers as to prices or conditions of sale according to different categories of their customers, this possibility was little used, not least because the administration chose not to define the categories of customer for this purpose: Charié Report (2008), 286.

${ }^{68}$ Charié Report (2008) 286.

${ }^{69}$ Loi de finances no. 63-628 du 2 juillet rectificative pour 1963 portant maintien de la stabilité économicque et financière, art 1 later codified as art 442-2(1) C Com.
} 
level as a loss-leader, but it was also intended to protect producers/suppliers, as it was thought that it would lead other retailers to put pressure on their own suppliers to align their prices with the lowest prices already set by their competitors. ${ }^{70}$ The intention was, therefore, to force retailers to take their profits by charging consumers more than the price which they paid to their own suppliers (a "front margin"). In practice, however, many retailers circumvented the prohibition of resale at a loss by keeping to the "tariff prices" set by their own suppliers in their CGVs, while at the same time charging them sums for supposed commercial services, including mere "commercial co-operation": these extra sums ("back charges") provided a "back margin" of profit for the retailers. ${ }^{71}$ Large retailers readily used their buying power to charge their suppliers for "services" in this way rather than require them to reduce their tariff prices; but to make up for these back charges (which in 2005 averaged $33.5 \%$ of net prices $^{72}$ ) suppliers increased their tariff prices for all their customers and not merely those who could impose back charges. And, given the prohibition of price discrimination by suppliers, small retailers had to pay the same (tariff) prices as large retailers, but, unlike large retailers, they lacked the market power to negotiate "back charges". This led to an inflationary spiral affecting all parties to the distribution of goods, including, of course, consumers. ${ }^{73}$ Unsurprisingly, this was seen as problematic by successive French administrations.

According to the Minister of Finance, Christiane Lagarde, the solution to these problems adopted by the legislation of 2008 was "to return contracts of distribution to the free negotiation of prices and contract terms in the interests of the greatest possible price competition", while at the same time preserving "intact the possibility of a really effective

\footnotetext{
${ }^{70}$ Hegelsteen Report, 8.

${ }^{71}$ Charié Report (2008) 287 - 288.

${ }^{72}$ Hegelsteen Report, 9. They ranged from $5 \%$ up to $70 \%$.

${ }^{73}$ Hagelstein Report, 9. Attempts to avoid these results, for example, by including all financial advantages in the calculation of the threshold of resale at a loss failed to have the desired effect: Charié Report (2008) 289 - 290.
} 
sanction of abuses committed in commercial relations, notably by reason of the imbalance in the power relationship of the parties in question., ${ }^{, 74}$ The 2008 legislation therefore prohibited back margins by subjecting charges for so-called commercial co-operation to severe financial sanctions, ${ }^{75}$ and it instead sought to facilitate "tariff discrimination", leaving to contracting parties "every latitude to conclude particular conditions of sale" supplier's CGVs should form the "unique basis of commercial negotiation", nevertheless "any producer, supplier of services, wholesaler or importer may agree with a buyer of products or possible customer of services individual conditions of sale which are not subject to the obligation of communication". 77

Again, though, liberalisation was seen as requiring detailed provision in the law of unfair competition so as to deal with the possible abuse of these new rights, to provide greater legal certainty and more effective enforcement. ${ }^{78}$ The new law therefore amended the Commercial Code so as to include in the list of possible "abuses" by traders " attempting to subject a commercial partner to obligations creating a significant imbalance in the rights and obligations of the parties" (art.442-6.I. $\left.2^{\circ}\right) .{ }^{80}$ Other "abuses" are also specified by art $442-6$, notably obtaining or attempting to obtain payments for non-genuine "commercial services" or to gain the acceptance of manifestly unfair terms governing prices or payment periods by threatening to break off commercial relations; breaking off commercial relations except subject to a series of conditions; and imposing price variation

\footnotetext{
${ }^{74}$ Lettre de mission to Mme Marie-Dominique Hegelsteen of 15 November, 2007 from Mdme Christine Lagarde, M Luc Chatel: Hegelsteen Report, 3.

${ }^{75}$ Charié Report (2008), 290; art L 441-7 C com. The main technique was to ensure that any charges made for other services were included within the calculation of the price agreed for the purposes of the transparency obligation.

${ }^{76}$ Charié Report (2008), 292.

${ }_{78}^{71}$ Art L 441-6.I(3) as amended by loi 2008 art 92.I.

${ }^{78}$ Hagelsteen Report, $22-23$.

${ }^{79}$ Charié Report, $292-293$.

${ }^{80}$ Between 2005 and its amendment in 2008 the provision concerned cases where the trader abused a relationship of dependence or of its power of purchase or sale by subjecting its partner to unjustified commercial conditions or obligations: art 442-6.I. $2^{\circ}$ as amended by loi no 2003-7 du janvier 2003 art 50(V); Muriel Chagny, 'Une (r)évolution du droit français de la concurrence? À propos de la LME du 4 août 2008' (2008) JCP.I.196 no 15.
} 
clauses. ${ }^{81}$ Proceedings under art $442-6$ can be brought by "any person showing an interest in doing so, by the ministère public, ${ }^{82}$ by the Minister for the Economy or by the President of the Competition Authority as regards a case within its competence ${ }^{83}$; they can be brought only before one of eight specialised commercial courts of first instance with any appeal being heard by the Court of Appeal of Paris. ${ }^{84}$ In addition to the imposition of liability and the possibility of an injunction, if sued by the relevant public authorities, a court has the power to impose a civil penalty. ${ }^{85}$ Public authorities therefore have an important role in the policing of this special law of unfair competition, but the traders affected may also claim. ${ }^{86}$

The adoption by art 442-6.I. $2^{\circ}$ of the central test of the unfairness of terms in consumer contracts in the French Consumer $\operatorname{Code}^{87}$ became important when art 442-6.I. $2^{\circ}$ was challenged before the French Constitutional Council (Conseil constitutionnel) by a group of nine major French retailers sued by the Minister of the Economy for use of allegedly unfair terms. ${ }^{88}$ The Constitutional Council upheld the constitutionality of the provision on the basis that the courts had already explained the notion of a "significant imbalance in the rights and obligations of the parties" in the consumer context and this meant that the behaviour it prohibits is sufficiently "clear and specific" so as not to breach the principle of the "legality" of criminal offences and penalties in art 8 of the Declaration of the Rights of Man $1789 .^{89}$

\footnotetext{
${ }^{81}$ Art 442-6-I. $1^{\circ}, 4^{\circ}-5^{\circ} \& 7^{\circ} \mathrm{C}$ com.

${ }^{82}$ The ministère public is a particular category of magistrat answerable to the Minister of Justice whose role in civil matters is to initiate or to join proceedings and submit arguments to the "sitting" judges (the magistrats $d u$ siège) as a matter of the public interest.

${ }^{83}$ Art L 442-6 III $1^{\text {st }}$ sentence C com.

${ }^{84}$ Art L 442-6 III last sentence; art D 442-3 C com.

${ }^{85}$ Below, p 00.

${ }^{86}$ Between 30 September 2009 and 5 November 2015 there were 101 decisions of cours d'appel on this provision only 8 of which concerned proceedings brought by the Minister of the Economy: Emmanuel Dieny, 'Déséquilibre significatif: sept ans après a-t-on attaint l'âge de raison? JCP 2015 Enterprise et affaires 1626, no 21.

${ }^{87}$ Art L 211-1 al 1 C consom (2016) implementing 1993 Directive art 3(1).

${ }^{88}$ Conseil constitutionnel no.2010-85 QPC du 13 janvier 2011, Etablissements Darty et Fils.

${ }^{89}$ Ibid, para 4. Under art 61(1) of the Constitution of the $5^{\text {th }}$ Republic of 1958 (as amended in 2008), any question of the constitutionality of parliamentary legislation arising in the course of proceedings in the ordinary or the administrative courts may be referred by the court to the Conseil constitutionnel for determination. Since
} 
But just how broad is this control of the terms of commercial contracts?

First, on its terms art 442-6.I. $2^{\circ}$ applies to "any producer, merchant, manufacturer or registered trader" (including a public body ${ }^{90}$ ) in their dealings with their "commercial partner" and most commentators agree that, despite its background, it is not limited to the context of the commercial distribution of goods ${ }^{91}$ and can therefore apply to any commercial contract, including contracts of hire, sub-contracts, insurance or credit, ${ }^{92}$ though some have argued (and some courts have accepted) that "commercial partnership" requires a degree of continuity and is to be distinguished from mere co-contractor. ${ }^{93}$ Art 442-6.I. $2^{\circ}$ has been seen as applicable to contracts of hire of security equipment, ${ }^{94}$ to provide managed hosting services for an on-line payment services company, ${ }^{95}$ to set up a web-site, ${ }^{96}$ to provide postal services for La Poste ${ }^{97}$ and to the contracts between Expedia (an internet travel and holiday company) and hoteliers. ${ }^{98}$ The Court of Appeal of Paris has indeed declared simply that art 442-6.I. $2^{\circ}$ can apply to any contract concluded between traders (professionnels) ${ }^{99}$ and this was also the view of the parliamentary rapporteurs in the course of the ratification of the later reform of the Civil Code, though they excepted contracts between persons in business but

\footnotetext{
the 1970s, the Conseil has developed a number of grounds of constitutionality (a bloc de constituionalité) drawn from the Declaration of the Rights of Man and the Preamble to the Constitution of the $4^{\text {th }}$ Republic as well as the Constitution of 1958 itself. The Conseil interpreted the requirement in art 8 of the 1789 Declaration that penalties must be established by parliamentary legislation (loi) as requiring that these penalties are sufficiently clear and specific: Conseil constitutionnel no.80-127 DC du 20 janvier 1981 Loi renforçant la sécurité et protégeant la liberté des personnes especially at para 7.

${ }^{90}$ Dimitri Delesalle and Nicholas Genty 'Vers un contrôle des clauses abusives dans les contrats entre professionnels' Petites affiches (17 May 2011) and see art L 410-1 C com.

91 Thomas Genicon in Denis Mazeaud and Thomas Genicon, 'Protection des professionnels contre les clauses abusives' (2012) Revue des contrats 276 at 279; Muriel Chagny, 'L'essor jurisprudential de la règle sur le déséquilibre significatif cinq ans après?' RTDCom. 2013.500, 502 - 503; Emilie Gicquiaud, 'Le contrat à l'épreuve du déséquilibre significatif' RTDCom 2014.267, 270.

92 Delesalle and Genty, n 90; Dieny, n 86, no 17 quoting CA Douai 13 septembre 2012 12/02832 to this effect.

${ }^{93}$ Marie Malaurie-Vignal, Contrats Concurrence Consommation (2016) Commentaires no 141, noting CA Aixen-Provence 10 mars 2016 no 2016/140.

${ }^{94}$ CA Paris 21 octobre 2011, $\mathrm{n}^{\circ} 10 / 12570$.

${ }^{95}$ Trib com ord réf 7 juin 2016, Ecritel c Cards Off noted by Grégoire Loiseau (2016) Communication

Commerce électronique, comm (July 2016) 60.

${ }^{96}$ CA Lyon 13 Janvier 2012, no. 10/08521.

${ }^{97}$ CA Paris 19 janvier 2011, France logistique v La Poste.

${ }^{98}$ CA Paris 21 juin 2017, RG n $15 / 18784$ Ministre de l'Economie v Groupe Expedia.

${ }^{99}$ CA Paris 1 octobre 2014 no 13/16336 at p 14 (in the context of a large retailer and its suppliers); Paris 12 décembre 2013 no 11/18274, Sarl Securitas France c Obligi et SARL securite protection ouest.
} 
whose contracts did not belong to droit commercial, for example, between members of a "liberal profession" (such as lawyers) and their clients. ${ }^{100}$ On the other hand, in practice the public enforcement authorities have focussed their attention on the large retail sector and the courts have only rarely actually applied art 442-6.I. $2^{\circ}$ outside this context. ${ }^{101}$

Secondly, art 442-6.I. $2^{\circ}$ does not require the existence of a relationship of economic dependence between the contracting parties as did its predecessor ${ }^{102}$ nor that the contract terms are in a standard form ${ }^{103}$ or are otherwise not individually negotiated. ${ }^{104}$ Instead, art 442-6.I. $2^{\circ}$ refers rather enigmatically to one party "subjecting or attempting to subject" the other to the imbalanced obligations in question, a formula which has encouraged the Commercial Chamber of the Cour de cassation to allow the courts of appeal a good deal of flexibility. ${ }^{105}$ For example, in one case the Court of Appeal of Paris's order stopping GALEC, a national supermarket company, from using certain terms in contracts with its suppliers, was challenged on the ground that "subjection" requires proof of an element of constraint, such as pressure or a threat. ${ }^{106}$ The Commercial Chamber disagreed, holding that the suppliers (only 3\% of which belonged to large groups) did not have "a real power of negotiation" and could not attempt to change the terms and therefore risked being de-listed by GALEC (which possessed 16.9\% of the retail market); the Court of Appeal was therefore entitled to decide that the suppliers had been "subjected" to GALEC's requirements within

\footnotetext{
${ }^{100}$ Below, p 00.

${ }^{101}$ Diego de Lammerville in Philippe Stoffel-Munck (ed) Réforme du droit des contrats et pratique des affaires (Dalloz, 2015) 62.

${ }^{102}$ Art 442-6.I. $2^{\circ}$ (b) $(2003-2008)$.

${ }^{103} \mathrm{Cf}$ below, p 00 regarding art $1171 \mathrm{C}$ civ (2016 and 2018). The control of terms in art 212-1 C consom is not restricted to terms "not individually negotiated" as foreseen by the 1993 Directive art 3 which it implements.

${ }^{104}$ Armand Dadoun, 'Faut-il avoir peur du "déséquilibre significatif" dans les relations commerciales?' (2011) 73 Petites affiches 17 at no 13.

${ }^{105}$ According to Dieny, n 86, nos 26 - 36 the courts of appeal generally adopt a two-stage approach requiring a proof of an imbalance in power and the absence of effective negotiation coupled with a resulting disproportionality of obligation.

${ }^{106}$ Com 27 May 2015, no 14-11387 (2nd moyen); Muriel Chagny, 'La règle sur le déséquilibre significatif devant la Cour de cassation!' RTDCom 2015.486, 487 -488.
} 
the meaning of art 442-6.I. $2^{\circ} .{ }^{107}$ Here, therefore, "subjection" refers to a difference in practical bargaining power rather than the mere presence of a standard contract term. ${ }^{108}$ In another case, however, the Commercial Chamber found the "submission" of one trader to another in the fact that the terms in question (which imposed penalties for failures in performance) formed part of a "pre-drafted annex [of the contract] which left no room free for the modification of its content, unlike two other annexes, and were not the subject of any real negotiation". ${ }^{109}$ Here, the lack of any possibility of negotiation of a standard form was enough. On the other hand, it has been said that a contracting party may be "subjected" to contract terms even where they did result from a degree of negotiation, notably where one party exploits the economic dependence of another. ${ }^{110}$

Thirdly, unlike the controls on unfair terms in the Consumer Code or the Civil Code, art 442-6.I. $2^{\circ}$ does not exclude from its scope contract terms which determine the price or the main subject-matter of the contract, ${ }^{111}$ reflecting its main purpose in controlling "abuses" of the freedom to negotiate prices as well as terms introduced in $2008 .{ }^{112}$ In this respect, the Court of Appeal of Paris has accepted that while "it is not for courts to fix prices which are free and a matter for contractual negotiation", nevertheless, they must "determine if the prices fixed by the contracting parties create, or created, an imbalance between them and whether this imbalance was of a sufficient importance to be classified as significant."113 Understandably, some French lawyers see this aspect of art 442-6.I. $2^{\circ}$ as creating a new

\footnotetext{
${ }^{107}$ Ibid.

${ }^{108}$ Chagny, n 106, 489.

${ }^{109}$ Com. 3 mars $2015,13-27525$ ( $8^{\text {th }}$ moyen $)$.

${ }^{110}$ Chagny, n 106, 488 referring to CA Paris 23 May 2013 no. 12/01166.

${ }^{111} \mathrm{Cf}$ art L 212-1 al 3 C consom; 1993 Directive art 4(2); art $1171 \mathrm{C}$ civ. Com 25 janvier 2017 no 15-23547, AJ Contrat 2017.132.

112 Chagny, n 91, 501 .

${ }^{113}$ CA Paris (pôle - Chambre 5) 23 mai 2013, no. 12/01166, l'arrêt IKEA; Com 25 janvier 2017 no 15-23547.
} 
general form of substantive imbalance in the contract (lésion) ${ }^{114}$ and complain about the resulting legal uncertainty. ${ }^{115}$

Fourthly, the Conseil constitutionnel's reference to consumer law in upholding the constitutionality of art 442-6.I. $2^{\circ}$ has suggested to some commentators that the courts should draw on the understanding of the consumer test in interpreting and applying the commercial test; unsurprisingly, others see this as entirely inappropriate! ${ }^{116}$ However, it is unlikely that the consumer case-law will help much, as French courts have not needed to explain the significance of "significant imbalance" there as the Consumer Code sets out a series of factors to be taken into account for this purpose ${ }^{117}$ and, since 2008, has provided a black-list of terms unfair in all circumstances and a grey-list of terms presumed to be unfair. ${ }^{118}$ According to the Cour de cassation, in the commercial context art 442-6.I. ${ }^{0}$ "invites an assessment of the context in which the contract is concluded and its overall economic purpose",119 and allows a particular "unbalanced term" to be compensated for by other, negotiated terms. ${ }^{120}$ However, according to Behar-Touchais, in practice the Court of Appeal of Paris distinguishes between cases involving large retailers and their suppliers (where the controls are applied very broadly including as to the level of the prices charged) and other cases (where most claims for the unfairness of the contract terms are rejected). ${ }^{121}$ In this

\footnotetext{
${ }^{114}$ Genicon, n 90, 282.

${ }^{115}$ Franck Tassan in Stoffel-Munck, n 101, 64.

${ }^{116} \mathrm{Cf}$ the views of Mazeaud and Genicon, n 91, at 283 - 284 as to the appropriateness of reference to the examples of unfair terms in the Consumer Code in the commercial context. The decision of the Conseil constitutionnel does not require commercial courts to follow the approach taken under the Consumer Code: Com 3 mars 2015 Eurauchan n 13-27525, Bull com 2015. IV n 42, noted by Chagny, n 106, but the commercial court can be "inspired" by the consumer black-list: CA Paris Pôle 5-ch.4 18 septembre 2013. ${ }^{117}$ Art 212-1(2) C consom (implementing art 4(1) of the 1993 Directive).

${ }^{118}$ Dadoun, $\mathrm{n} 104$ at no 9. These lists are now contained in art R 212-1 - 212-5 C consom. The 1993 Directive requires only an "indicative list" of terms which may be unfair: art 3(3) and Annex.

${ }_{119}$ Com 3 mars 2015 Eurauchan, n 115 (6 $6^{\text {th }}$ moyen $)$.

${ }^{120}$ Gaël Chantepie, 'Le déséquilibre significatif au miroir de la Cour de cassation' AJ Contrats d'affaires Concurrence - Distribution 2015.218 at 218 - 219 referring to Com 3 mars 2015 Eurauchan; cf Gicquiaud, n 91, no 17 who argues that the lower courts' decisions tend to identify certain categories of term which are or are not objectionable.

${ }^{121}$ Martine Behar-Touchais, 'Un déséquilibre significatif à deux vitesses' (2015) JCP.I.603; Dieny, n 86, nos 24 $\& 25$ (10\% of proceedings brought by the Ministry; $58 \%$ of decisions actually find the unfair practice).
} 
way, she argues, the courts have "corrected" the "legislative defect" in the drafting art 4426.I. $2^{\circ}$ which on its terms applies to all commercial contracts even though its proper concern was with supply contracts made by large retailers. ${ }^{122}$

Finally, committing the unfair commercial practice described in art 442-6.I. $2^{\circ}$ may attract the imposition of liability in damages or the award of an injunction (including at the request of the contracting party ${ }^{123}$ ), but art 442-6 itself empowers only the enforcement authorities to ask for the annulment of an offending contract term or contract, with any consequential restitution as necessary. ${ }^{124}$ Nonetheless, the courts allow claims by traders for a term to be treated as "not written" and so ineffective. ${ }^{125}$ In addition, the designated public authorities may ask a court to impose a civil penalty of up to 2 million euros or up to $5 \%$ of the defendant's net turnover in France! ${ }^{126}$

Overall, the Commercial Code empowers French courts to find that the "subjection" by a trader of its "commercial partner" to its terms (including as to the price) constitute an abuse of competition, with a range of consequences, some quasi-penal and some affecting the relative position of the contracting parties. The deregulation of prices and terms in the largescale retail sector therefore led, perhaps inadvertently, to the creation of a broad control on the fairness of the bargain as well as the fairness of incidental terms in commercial contracts generally.

\footnotetext{
${ }^{122}$ Behar-Touchais, ibid, at no 18.

123 "[A]ny person with an interest" can so claim: art L 442-6-III(1).

${ }^{124}$ Art L 442.6.III(2) C com.

${ }^{125}$ See, notably, Paris CA 7 juin 2013, no 11-08674 cited to this effect by Sacha Houlié, Député, Rapport on behalf of Commission des lois constitutionnelles, de la législation et de l'administration générale de la République, sur le projet de loi, adopté part le Sénat, Assemblé nationale No 429 (29 Nov 2017) (Houlié Report 2017) at 70. See also Muriel Chagny, 'La généralisation des clauses abusives (articles 1168 et 1169 du Code civil)' in Stoffel-Munck, n 101, 47 at 53; Gicquiaud, n 90, no 30.

${ }^{126}$ Art0 L 442.6.III al 2 C com. This second possibility was introduced by loi no. 2015-990 du 6 aôut 2015 pour la croissance, l'activité et l'égalité des chances économiques, art 34.
} 


\section{Unfair terms in contrats d'adhésion in the reformed Civil Code}

The provisions of the Civil Code governing the law of obligations in general and the law of contract in particular remained all but untouched for two centuries after their enactment in 1804, but the law as applied by the courts changed significantly, sometimes radically, and for French lawyers this reliance on a fluctuating case-law created legal uncertainty. ${ }^{127}$ After some ten years of academic and official draft instruments, ${ }^{128}$ the French government obtained parliamentary authority to reform the Civil Code by ordonnance, a special form of executive legislation, despite the opposition of the French upper house, the Sénat. ${ }^{129}$ A draft was published for consultation by the Ministry of Justice in February $2015^{130}$ and the ordonnance itself was enacted in February 2016, coming into force on 1 October 2016 for contracts made on or after that date. ${ }^{131}$ However, a particular constitutional feature of legislating by ordonnance in this way is that the new law so-created enjoys only the status of executive regulation (règlement) and is therefore open to review on the grounds of its constitutionality before the administrative courts unless it is ratified by special parliamentary legislation (loi). ${ }^{132}$ Therefore, in 2017 the French government introduced a parliamentary bill simply to ratify the ordonnance, but the French Parliament (and in particular the Sénat) refused to do so

\footnotetext{
${ }^{127}$ See generally on the process of reform Bénédicte Fauvarque-Cosson, Juliet Gest and François Ancel, 'The Process of Elaboration of the Reform of the Law of Contract' in Cartwright and Whittaker, n 7, ch 2.

${ }^{128}$ The two academic instruments were Pierre Catala (ed), Avant-projet de réforme du droit des obligations et de la prescription: Rapport remis au garde des Sceaux (Paris, Documentation française, 2006); F Terré (ed), Pour une réforme du droit des contrats (Paris, Dalloz, 2009). The Ministry of Justice constructed its own preliminary draft in 2008 which was distributed informally.

${ }^{129}$ Loi no $2015-177$ of 16 février 2015 art 8 as foreseen by art 38 of the Constitution. Art 8 was approved as constitutional by the Conseil constitutionnel No 2015-710 DC of 12 février 2015.

${ }^{130}$ Ministère de la justice, Projet d'ordonnance portant réforme du droit des contrats, du régime général et de la preuve des obligations (25 Feb 2015) (Projet d'ordonnance 2015).

${ }^{131} 2016$ Ordonnance art 9.

132 Art 38 Constitution (referring to an unratified ordonnance as being caduque). See further François Piller, Sénateur, report on behalf of the Commission des lois constitutionelles, de légilsation, du suffrage universel, du Règlement et de l'administration générale, Sén no 22 (11 Oct.2017) (Pillet Report 2017) 11 - 12.
} 
without amendment, although these amendments were restricted in a "spirit of responsibility" to provisions seen as politically significant or needing clarification. ${ }^{133}$

One of the most striking innovations of the 2016 Ordonnance was its creation of a new general judicial power to review the fairness of contract terms. ${ }^{134}$ The provision initially proposed by the Ministry was not restricted to the terms of contrats d'adhésion but this attracted considerable criticism from the business world which was worried about its effect on transaction certainty and on the attractiveness of French law. ${ }^{135}$ As enacted in 2016, therefore, the test of fairness in article 1171 was restricted to the terms of les contrats d'adhésion defined by art 1110 as ones "whose general conditions are determined in advance by one of the parties without negotiation."136 According to the Ministry, this change protects the "weaker party", establishes coherence with the legislative controls on unfair terms in consumer contracts and in commercial contracts, and reflects wider European developments in European instruments, such as the Principles of European Contract Law and the Draft Common Frame of Reference, and the proposed Common European Sales Law. ${ }^{137}$ Article 1171 provided that:

Any term of a contrat d'adhésion which creates a significant imbalance in the rights and obligations of the parties to the contract is deemed not written.

\footnotetext{
${ }^{133}$ Piller Report 2017 at 7.

${ }^{134}$ Arts 1110 and $1171 \mathrm{C}$ civ (2016).

${ }^{135}$ Rapport au Président de la République relatif à l'ordonnance $n^{\circ} 2016-131$ du 10 février 2016 portant réforme du droit des contrats, du régime général et de la preuve des obligations (Rapport au Président) JO République française no. 35 (11 février 2016) texte ${ }^{\circ} 25$ (unpaginated) 11. Cf Projet d'ordonnance 2015 art 1169

${ }^{136}$ Art 1110 al 1 (2016) also defined a "bespoke contract" (le contrat de gré à gré) as "one whose stipulations are freely negotiated by the parties."

${ }^{137}$ Rapport au Président, 2 \& 3. For the European instruments see especially art 4:110 PECL; Art 4:110 Principes contractuels communs; arts II.-9:401 - II.-9:408 DCFR (esp art II.-9:405); and Proposed Common European Sales Law art 86.
} 
The assessment of significant imbalance must not concern either the main subjectmatter of the contract nor the adequacy of the price in relation to the act of performance. $^{138}$

However, in the course of ratification of the Ordonnance of 2016 while the Assemble nationale and the Sénat agreed that the new control should apply only to the terms of contrats d'adhésion, they disagreed as to how those contracts should be defined. The Sénat thought that the notion of "general conditions" used by art 1110 was unclear and that the definition should rest on lack of negotiability rather than of negotiation of the terms, a view which was finally accepted by the Assemblé nationale. As a result, art 1110 as ratified defines a contrat d'adhésion as "one which comprises a collection of non-negotiable terms which are determined in advance by one of the parties"139 and art 1171 applies only to contract terms which were "not negotiable, determined in advance by one of the parties." also avoided the earlier problem that the controls in art 1171 appeared to apply to all the terms of a contract using "general conditions" even where the terms in question were themselves negotiated. ${ }^{141}$

The parliamentary process of ratification also revealed the perceived justification for the new controls. Sénateur Pillet, the rapporteur to the relevant Sénat committee, noted the traditional concerns with the quality of the "will" of a contracting party on whom the other has imposed a set of terms ${ }^{142}$ and explained that the restriction to contrats d'adhésion explains how controls can properly be included in the "general law" in the Civil Code which

\footnotetext{
${ }^{138}$ Art 1171 is not the only provision controlling the validity of contract terms: ordre public remains as a possible ground of invalidity (art 1102 al 2) and art 1170 provides that "[a]ny contract term which deprives a debtor's essential obligation of its substance is deemed not written", a control which reflects the well-known case-law noted above, n 33 .

${ }^{139}$ Art 1110 al 2 (2018).

${ }^{140}$ On the interpretation of these expressions see Olivier Deshayes, Thomas Genicon and Yves-Marie Laithier, Réforme du droit des contrats, du régime générale et de la preuve des obligations (LexisNexis, Paris, $2^{\text {nd }}$ ed 2018), $347-350$.

${ }^{141}$ The former version of art 1171 controlled "[a]ny term of a contrat d'adhésion" where the latter was defined according to the lack of negotiation of the contract's "general conditions": above, $p$

${ }^{142}$ Pillet Report 2017, 30 referring to Raymond Saleilles, above n 30.
} 
is "marked by the equality of the parties" to the contract unlike the controls governing consumer and commercial contracts where the parties are "structurally unequal". ${ }^{143}$ In his view, a contrat d'adhésion "is characterised by the fact that one party proposes the contract without permitting the other to discuss all or part of its stipulations"; where a party accepts a set of terms without choosing to discuss them, it is highly debateable whether they can later claim that they are unfair. This was why the proper touchstone for judicial review was seen as "negotiability", that is, whether the party could have affected the content of the term, rather than actual negotiation. ${ }^{144}$ To these arguments, Deputé Houlié added that the new controls reflected the wider concern of the reforms with contractual justice, here requiring the protection of a weaker party to a contract where neither freedom nor equality are present. ${ }^{145}$ In the result, the new wording reflects the justification for judicial review in a lack of opportunity to negotiate the "collection of terms", but where terms are negotiable (even if not negotiated) they can reflect the parties "wills" and therefore their contractual freedom. ${ }^{146}$

What is not seen in the parliamentary debates nor in legal commentaries ${ }^{147}$ is the idea (prominent in modern German legal scholarship) that use of standard form contracts leads to a partial market failure in that it is futile for the party facing the other party's standard terms to spend time or money in trying to renegotiate them. ${ }^{148}$ This reflects, I think, a wider antipathy in French legal circles to arguments from "law and economics" which are seen as alien to the French protective model of contract (which adopts a moral rather than an

\footnotetext{
${ }^{143}$ Ibid, $30-31$.

${ }^{144}$ Ibid, 31.

${ }^{145}$ Houlié Report 2017, 17 - 18.

${ }^{146}$ Deshayes, Genicon and Laithier, n 140, 348 and 349.

${ }^{147}$ For a classic doctrinal discussion see Thiery Revet, 'Les critères du contrat, Article 1110 nouveau du code civil' D 2016.1771.

${ }^{148}$ See R. Zimmermann, The New German Law of Obligations, Historical and Comparative Perspectives (OUP, Oxford, 2005) 175 - 176.
} 
economic view) and all too redolent of the utilitarian values of "Anglo-Saxon" common law. ${ }^{149}$

But what is the scope of application of these controls? As part of "general contract law," art 1171 of the Civil Code can apply in principle to any type of private law contract, whatever its subject-matter and whatever the character of its contracting parties (business, non-business etc.), ${ }^{150}$ but their practical significance depends on their relationship to earlier controls on unfair terms in consumer and in commercial law. In principle, "special rules derogate from general rules" $" 151$ and, according to the Ministry of Justice, this means that it is impossible to apply both the controls in the Civil Code and in one of the special regimes, whether commercial or consumer, but in Sénateur Pillet's view the mere silence of a special regime does not mean that the general regime in the Civil Code can apply instead as "the application of the general law cannot lead to distorting the coherence or disregarding the spirit of the special law". ${ }^{152}$ This suggests that cases falling under the commercial or consumer regimes cannot attract the controls in the Civil Code and, if one leaves aside consumer contracts and commercial contracts understood broadly, ${ }^{153}$ art 1171 would apply only to contracts between private individuals (for example, where they use a web platform to buy and sell goods terms on terms set by the platform provider ${ }^{154}$ ) and contracts between two or more persons in business which do not count as "commercial" (notably, contracts between

\footnotetext{
${ }^{149}$ According to Deputé Houlié, art 1171 reflects the fact that French law is more protective than "AngloSaxon” laws: Houlié Report 2017, 27.

${ }^{150}$ In principle, "administrative law contracts" are governed by administrative contract law rather than private law, but it is possible that the Conseil d'Etat will be "inspired" to follow the lead taken by article 1171 subject, to public law principle and the needs of the 'public service': cf Laurent Richer and François Lichère, Droit des contrats administratifs (LGDJ, Paris, 10 ${ }^{\text {th }}$ edn, 2016) 37 - 39 explaining the use of the Civil Code by administrative courts despite the "autonomy" of administrative contract law.

${ }^{151}$ A traditional interpretative maxim, but codified in art 1105 al $3 \mathrm{C}$ civ (2016) as regards special rules governing particular "nominate" contracts in the Civil Code itself.

152 Pillet Report 2017, $22-23$.

${ }^{153} \mathrm{Cf}$ above, p 00 on the scope of application of art L 442-6.I $2^{\circ} \mathrm{C}$ com.

${ }^{154}$ Houlié Report 2017, 72.
} 
members of a "liberal profession" such as lawyers and their clients). ${ }^{155}$ In the case of consumer contracts, consumers are likely to rely on the consumer provisions which are generally more protective. ${ }^{156}$ Beyond this, it could be argued that a contract term which passes the controls in the Commercial Code could nevertheless fail the test in the Civil Code. ${ }^{157}$ For example, if a commercial court finds that one trader has not "subjected" the other trader to the contract term in question so as to fall under art.L442-6.I. $2^{\circ}$, a civil court could still find that the term formed part of a contrat d'adhésion so as to fall under art 1171 of the Civil Code. A commercial contract could, therefore, be subject to each control in succession. $^{158}$

Art 1171(2) follows the Consumer Code by providing that:

The assessment of significant imbalance must not concern either the main subjectmatter of the contract nor the adequacy of the price in relation to the act of performance.

The purpose of this is clear. Article 1171 is not to be used by the courts for the control of the core elements of the contract: it is a control of unfair ancillary matters rather than a control of the substantive fairness of the contract itself. ${ }^{159}$ However, unlike the position in consumer law, the exclusion is not conditional on the term being drafted in a clear and comprehensible manner ${ }^{160}$ and this appears to mean that, for example, a term setting the level of a price or the main subject-matter of the contract must not be reviewed under art 1171 whether or not it is

\footnotetext{
${ }^{155}$ Ibid. The Pillet Report 2017, 61 considers that "commercial leases" (les baux commerciaux) made by "institutional lessors" would also fall under art 1171. According to Deshayes, Genicon and Laithier, n 140, 346 art.L442-6.I. $2^{\circ}$ applies only where the underlying contract concerns an activity "of production, distribution or services" citing Com 15 février $2018 \mathrm{~N}^{\mathrm{o}}$ 17-11329 which excluded a commercial lease from its scope on this ground. However, this restriction is made by art.L442-1 for the purposes of its own provisions and is therefore arguably inapplicable to art.L442-6.I. $2^{\circ}$.

${ }_{157}^{156}$ Xavier Lagarde, 'Questions autour de l'article 1171 du code civil' D 2016.2174, 2175

${ }^{157}$ See further Deshayes, Genicon and Laithier n 140, $342-347$.

${ }^{158}$ Karl Lafaurie, 'Clauses abusives: l'articulation du dispositifs du Code civil avec les textes spéciaux' JCP 2017 Entreprises et affaires no 1453, no 2.

${ }^{159}$ The reference to "ancillary terms" is taken from the judgement of the CJEU in Kásler v OTP Jelzálogbank Zrt (C-26/13) of April 30, 2014 at paras 49-50.

${ }^{160}$ Art L 212-1(3) C consom (2016) reflecting the 1993 Directive art 4(2).
} 
"clear and comprehensible" from the point of view of the person subject to it. ${ }^{161}$ This feature of art 1171 also distinguishes it from the controls governing commercial contracts which can apply to any term and are particularly significant for price terms. ${ }^{162}$

\section{English law: contractual principles and their exceptions}

English courts have long accepted that, once agreed, the principles of freedom of contract and the binding force of contracts oppose controls on the effectiveness of the terms of contracts and they have rejected the recognition of such controls at common law. ${ }^{163}$ There are, of course, exceptions to this picture, notably as regards exclusions of liability for personal fraud (which are ineffective ${ }^{164}$ ), covenants in restraint of trade (which are subject to a test of reasonableness), ${ }^{165}$ and penalty clauses (which are ineffective where they impose "a detriment on the contract-breaker out of all proportion to any legitimate interest of the innocent party in the enforcement of the primary obligation"). ${ }^{166}$ This absence of direct controls threw more weight on the rules governing the incorporation of terms (by requiring reasonable notice in the absence of signature ${ }^{167}$ ) and on the rules governing the construction of contracts, but, since the advent of legislative controls, English courts have tended to

\footnotetext{
${ }^{161}$ In the context of consumer law, the CJEU has explained that the notion that a term be "clear and comprehensible" must be understood from the point of view of the "average consumer": Kásler v OTP Jelzálogbank Zrt at para 74.

${ }^{162}$ Above, p 00.

${ }^{163}$ On these principles, see Chitty on Contracts paras 1-031 et seq (S Whittaker). Photo Production Ltd $v$ Securicor Transport Ltd [1980] AC 827 at 844, 847 overruled Harbutt's "Plasticine” Ltd v Wayne Tank \& Pump Co Ltd [1970] 1 Q.B. 447 which had accepted a legal doctrine of fundamental breach of contract. ${ }^{164} S$ Pearson \& Son Ltd v Dublin Corp [1907] AC 351, 353, 362; HIH Casualty and General Insurance Ltd $v$ Chase Manhattan Bank [2003] UKHL 6, [2003] 2 Lloyd's Rep 61.

${ }^{165}$ Chitty on Contracts paras 16-106 et seq.

${ }^{166}$ Cavendish Square Holding BV v El Makdessi, ParkingEye Ltd v Beavis [2015] UKSC 67, [2015] 3 WLR 1373 at [32] per Lord Neuberger PSC and Lord Sumption JSC (with whom Lord Carnwath JSC and Lord Clarke JSC agreed).

${ }^{167}$ L'Estrange v Graucob [1934] 2 KB 394 (signature); Interfoto Picture Library Ltd v Stiletto Visual Programmes [1989] 1 QB 433 (onerous nature of the term is relevant to reasonableness of the notice).
} 
abandon traditional, protective approaches to construction such as under the maxim contra proferentem. $^{168}$

In terms of legislation, the broadest exception to this picture is found in relation to the terms of consumer contracts now contained in Pt 2 of the Consumer Rights Act $2015 .{ }^{169}$ This follows the scheme of the European Directive very closely except that it applies the test of unfairness to terms whether or not they are "individually negotiated" and it retains the special control on exclusions of liability for negligence causing death or personal injury drawn from the Unfair Contract Terms Act 1977 (which no longer applies to consumer contracts). ${ }^{170}$ For other contracts, the most important exceptions to the general effectiveness of contract terms remain in the 1977 Act, but its broadest control on the "written standard terms of business" applies only to exemption clauses ${ }^{171}$ and to terms which allow a party to "render a contractual performance substantially different from that which was reasonably expected of him, or ... in respect of the whole or any part of his contractual obligation, to render no performance at all", such as some types of variation clause. ${ }^{172}$ Moreover, this control does not apply to some important types of contract (including contracts of insurance and for the creation or transfer of intellectual property or of securities ${ }^{173}$ ), to international supply contracts ${ }^{174}$ nor to contracts governed by English law only by reason of choice of law. ${ }^{175}$

\footnotetext{
${ }^{168}$ Nobahar-Cookson v Hut Group Ltd [2016] EWCA Civ 128, [2016] 1 C.L.C. 573 and see Chitty on Contracts, para 15-012. A statutory form of contra proferentem applies to consumer contracts: 2015 Act s 69. ${ }^{169}$ Replacing the Unfair Terms in Consumer Contracts Regulations 1999 (SI 1999/2083).

${ }^{170} 2015$ Act ss 65 - 66 and cf s 2 of the 1977 Act. The other change to the scope of the general controls in s 62 of the 2015 Act from the 1993 Directive is found in relation to the "core exclusion" in s 64 implementing and apparently extending the consumer's protection as compared with art 4(2) of the 1993 Directive: on this see Chitty on Contracts paras 38-394 - 38-399 (S Whittaker) which doubts the reality of this extension given the broad interpretation given to the proviso for the application of the exclusion that the relevant terms are in "plain intelligible writing" by the CJEU in Kásler v OTP Jelzálogbank Zrt (C-26/13).

${ }_{171}^{171}$ Defined broadly by 1977 Act s 13 .

1721977 Act s 3(2)(b) and see Chitty on Contracts Vol 1, paras 15-085 - 15-086 (S Whittaker). The 1977 Act s 2 also controls the exclusion of business liability for negligence and of liability for breach of implied terms in contracts of sale of goods etc in ss $6 \& 7$ of the Act, neither of which are restricted to standard terms.

1731977 Act s 1(2), Sched 1 para 2(a), (c) - (e).

1741977 Act s 26.

${ }^{175} 1977$ Act s 27(1).
} 
In looking at the 1977 Act, we can notice first the more neutral expression used to describe the terms controlled: unlike the French contrat d'adhésion, which draws attention to the lack of proper consent of the party subject to the terms, they are described as standard terms, an expression which (before the 1977 Act) had no technical meaning but which was understood as referring to the situation where one of the parties habitually makes contracts of the same type in a particular form (that is, set of terms) with little if any variation allowed from that form. ${ }^{176}$ The Law Commissions saw the justification for creating some control over terms in standard contracts between persons in business as being "the lack of negotiation that exists in most situations where they are used", but they did not consider that the "lack of negotiation, or of any opportunity for negotiation" could be regarded as the distinguishing feature of this type of contract, as there may be negotiation of some terms (such as quantity or price) even though the exemption clauses (which were the focus of the Law Commissions' attention) were proffered on a "take it or leave it" basis. ${ }^{177}$ They therefore recommended that the lack of opportunity to vary or negotiate terms should not be made a feature of the statutory definition of standard terms ${ }^{178}$ and this is reflected in the 1977 Act's reference simply to "written standard terms of business." 179 In considering this formula, the courts have held that "it has to be shown that that other party habitually uses those terms of business" which includes the term challenged: it is not enough that a model form has, on the particular occasion, been used. ${ }^{180}$ Moreover, where negotiations have in fact taken place around standard terms before the contract is made, and amendments agreed, it is a question of fact whether one party can be said to have dealt on those standard terms. ${ }^{181}$ The burden of

\footnotetext{
${ }^{176}$ Law Commission, Scottish Law Commission, Second Report on Exemption Clauses, Law Com No 69, Scot Law Com No 39 (1975) para 151 referring to H B Sales, 'Standard Form Contracts' (1953) 16 MLR 318.

${ }^{177}$ Ibid, para 156.

178 Ibid, paras $156-157$.

179 S 3.

${ }^{180}$ African Export-Import Bank v Shebah Exploration and Production Co Ltd [2017] EWCA Civ 845, [2018] 1

WLR 487 at [20] per Longmore LJ (with whom Henderson LJ agreed).

${ }^{181}$ University of Wales v London College of Business Ltd [2015] EWHC 1280 (QB) at [93].
} 
proof on this issue lies on the person claiming to be subject to the standard terms ${ }^{182}$ and it is unlikely to be discharged where the contract has been subject to substantial variations, even if these do not relate to the contract term (typically an exemption clause) challenged. ${ }^{183}$ The starting-point for the English law, therefore, is with the standard nature of the terms (their habitual use) rather than merely being prepared in advance (as in French law), but that, once this test is satisfied, the question whether or not the terms are "standard" depends on a combination of actual negotiation and negotiability. It must be remembered, though, that in English law this issue relates only to exemption clauses and certain related terms rather than (as in the French context) to the majority of contract terms. ${ }^{184}$

In 2005 the Law Commissions considered reforming the law of unfair terms (consumer and non-consumer) and recommended the extension of the general scheme governing consumer contracts to contracts made with small businesses, ${ }^{185}$ on the ground that they are unlikely to understand standard terms and that, even if they do, imbalances of power between them and their business partners may create "market distortions." "186 For contracts other than those with a small business, the Law Commissions recommended that the existing scheme of control in the 1977 Act should be retained, tying the controls more firmly to the use of standard terms. ${ }^{187}$ In doing so they considered whether the legislative controls should formally be restricted to cases where the protected business had no opportunity to negotiate a

\footnotetext{
${ }^{182}$ British Fermentation Products Ltd v Compair Reavell Ltd [1999] 2 All E.R. (Comm) 389 at [49].

${ }^{183}$ African Export-Import Bank $v$ Shebah Exploration and Production Co Ltd [2017] EWCA Civ 845 at [25], [35] \& [36] (Longmore LJ with whom Henderson LJ agreed).

${ }_{184}^{184}$ Above, p 00.

${ }^{185}$ Law Commission, Scottish Law Commission, Unfair Terms in Contracts, Law Com No 292, Scot Law Com No 199 (2005).

${ }^{186} \mathrm{Ibid}$ at paras 5.16 and 5.19 .

${ }^{187} \mathrm{Ibid}$ at paras $4.21-4.29$. It recommended that the special controls on the exclusion of liability for breach of the statutory implied terms in ss 6(3) and 7(3) of the 1977 Act (which are not restricted to standard terms) should not be retained: ibid at 4.25-4-29.
} 
standard term and was therefore genuinely taken by surprise, but, they concluded that this was unworkable. ${ }^{188}$

However, the new legislation on unfair terms as enacted in the 2015 Act did not follow the Law Commissions' recommendations. Instead of extending the controls on unfair terms in consumer contracts to commercial contracts made with small businesses, the new Act separated the law governing terms in consumer contracts (contained in the 2015 Act itself) and the law governing (mostly) exemption clauses remaining in the 1977 Act. In doing so, it abolished the category of persons "dealing as consumer" used by the 1977 Act, thereby removing the protection of section 3 from persons (including corporate persons) who did not contract as an integral part of their business and, if it was only incidental to it, was not of a type regularly entered: ${ }^{189}$ section 3 therefore applies now only to cases where one person is dealing on the other's written standard terms of business. ${ }^{190}$ Apart from the 1977 Act, particular legislative qualifications exist on the validity of terms in particular commercial contexts, for example, the late payment of commercial debts ${ }^{191}$ or "basis of the contract clauses" in non-consumer contracts of insurance. ${ }^{192}$

Furthermore, the general attachment of English judges to the principles of freedom of contract and the binding force of contract provides one of the reasons to explain the absence of any general requirement of good faith in contracting parties, whether this is expressed as a legal requirement or a general implied term. ${ }^{193}$ As regards the latter, it has been suggested recently judicially that there should be an implied term as to good faith at least in "relational"

\footnotetext{
${ }^{188}$ Ibid at paras $4.13-4.16$ and cf above, p 00.

${ }^{189} R$ \& B Customs Brokers Co Ltd v United Dominions Trust Ltd [1988] 1 WLR 321.

${ }^{190}$ Unfair Contract Terms Act 1977 s 3 (as amended by the 2015 Act).

${ }^{191}$ Late Payment of Commercial Debts (Interest) Act ss 7 - 10 (as amended).

${ }^{192}$ Insurance Act 2015 s. 9, 16(1).

${ }^{193}$ See further Chitty on Contracts, paras 1-043 - 1-063 (S Whittaker), noting the exceptions and qualifications.
} 
commercial contracts. ${ }^{194}$ This idea has not generally found favour with the courts. For example, Moore-Bick LJ has observed that:

"There is ... a real danger that if a general principle of good faith were established it would be invoked as often to undermine as to support the terms in which the parties have reached agreement." 195

There are also other important absences in terms of legal principle in the English approach, for, unlike French law, English law possesses no general principle or independent concept of the abuse of rights ${ }^{196}$ nor any general legal principle of unfair competition. As regards the latter, while there are a number of particular grounds of claim provided to a trader who is prejudiced by another trader's commercial conduct (including the tort of passing-off, the tort of intimidation, and the various protections provided for intellectual property), these are seen as having their own distinct remits rather than forming part of a wider law of "unfair competition". ${ }^{197}$ As with unfair contract terms, the most important exception to this pattern can be seen in the consumer context, itself derived from EU law, where there is a general prohibition of unfair commercial practices partly for the protection of consumers and partly

\footnotetext{
${ }^{194}$ Yam Seng Pte Ltd v International Trade Corp Ltd [2013] EWHC 111 (QB), [2013] Lloyd's Rep. 526 esp at [143] (Leggatt J); Al Nehayan v Kent [2018] EWHC 333 (Comm) at [167]-[176] (Leggatt LJ at [174]). ${ }^{195}$ MSC Mediterranean Shipping Co. S.A. v Cottonex Anstalt [2016] EWCA Civ 789 at [45] rejecting the approach of Leggatt $\mathrm{J}$ at trial, who had earlier given judgment in Yam Seng Pte Ltd v International Trade Corp Ltd [2013] EWHC 111 (QB).

${ }^{196}$ This position is generally associated with the decision of the HL in Bradford Corp v Pickles [1895] AC 587. See generally J. Limpens, R. M. Kruithof and A. Meinertzhagen-Limpens, "Liability for One's Own Act" in International Encyclopedia of Comparative Law, Vol XI, Torts, Ch 2 (1980) para 2.233.

${ }^{197}$ Stephen Weatherill, 'United Kingdom', Annex to Reiner Schulze \& Hans Schulte-Nölke (eds), Analysis of National Fairness Laws aimed at Protecting Consumers in Relation to Commercial Practices (June 2003) 9. Cf Richard Arnold, 'English Unfair Competition Law' (2013) 44 International Review of Intellectual Property and Competition Law 63 arguing that, although there is no general tort of unfair competition in English law, its inclusion of many particular forms of unfair competition justify the recognition that there is an English law of unfair competition. According to Iain Ramsay (writing in 1989) "fair trading" was seen as a matter for a combination of self-regulation (via the encouragement of industry codes of conduct), ad hoc intervention by a public body or bodies as needed and a restricted range of regulatory criminal offences, primarily concerned with misstatements concerning the description of goods: Consumer Protection, Text \& Materials $\left(1^{\text {st }}\right.$ edn, Weidenfeld \& Nicolson, London, 1989) 270.
} 
in the interests of other traders. ${ }^{198}$ In this respect, the relationship between the laws governing unfair business to consumer commercial practices and unfair contract terms is a close one, as use of an unfair term by a trader may constitute an unfair commercial practice. ${ }^{199}$ An important example of the regulation of an unfair commercial practice affecting the validity of terms as between two traders may be found in legislation governing late payment of commercial debts, whose purpose is to protect commercial creditors from being kept waiting for payment and which invalidating unreasonable unfair contract terms affecting the payment of statutory interest. ${ }^{200}$

Nevertheless, this background still contrasts very sharply with the French position, where the principles of freedom of contract and the binding force of contract are countered by the principle of good faith, and where the constitutional principle of freedom of commerce is countered by the idea that this freedom should not be abused, an idea given legal expression by the law of unfair competition. ${ }^{201}$ However, the English picture would remain incomplete without reference to the controls on unfair practices and unfair terms created after investigation by the UK competition authorities of potential anti-competitive practices of the large retail grocery sector in relation to their suppliers. ${ }^{202}$

\section{Promoting competition and fairness in the UK groceries sector}

\footnotetext{
${ }^{198}$ See Unfair Commercial Practices Directive 2005 recital 5. The 2005 Directive is implemented in UK law by the Consumer Protection from Unfair Trading Regulations 2008 (SI 2008/1277).

${ }^{199}$ Pereničovà v SOS finance, spol. sro (C-453/10) [2012] 2 CMLR 28 and see Chitty on Contracts, para 38278.

${ }^{200}$ Late Payment of Commercial Debts (Interest) Act 1998 s 14 implementing and extending the control foreseen by Directive 2011/7/EU on combating late payment in commercial transactions art 3(4) and (5). 201 Above, p 00.

${ }^{202}$ In 2017 the office of Small Business Commissioner was created whose role is to help small businesses which are unfairly treated by larger businesses as regards payment for the goods or services which they supply, as well as providing advice to them more generally: Enterprise Act $2016 \mathrm{Pt} 1$ and see https://www.smallbusinesscommissioner.gov.uk/ (accessed 5 Dec 2018).
} 
The Grocery Supply Code of Practice imposes on listed grocery retailers a general requirement of fair dealing with their suppliers and provides that any terms on which they deal must not be inconsistent with the Code. These controls originated in a "market investigation reference" of the grocery retail sector made by the then Office of Fair Trading under powers provided by Pt 4 of the Enterprise Act 2002 in situations where it suspects that any "feature or combination of features" of a market prevent, restrict or distort competition in the UK or part of it. ${ }^{203}$ The market investigation regime recognises that not every market failure can be cured through the application of the classic prohibitions found in articles 101 and 102 TFEU and their domestic analogues; ${ }^{204}$ it focuses on markets rather than on the behaviour of individual firms and enables the Competition and Markets Authority (formerly the Competition Commission) to investigate whether features of the market have an adverse effect on competition and allows a wide variety of measures to be adopted to correct this. ${ }^{205}$ The case of the retail grocery supply provides a particularly nice example of the nature of the analysis of competition which these investigations entail and of the "remedies" which the regulator may impose - and in the very same sector which has formed the context of the French reforms of commercial law. ${ }^{206}$

In the case of the supply of retail groceries, the Competition Commission identified a number of positive features about the market and considered that aspects of it were not anticompetitive. In particular, it did not see the purchasing power of the large retailers

\footnotetext{
${ }^{203}$ Enterprise Act 2002 s 131 . The powers are now possessed by the Competition and Markets Authority.

${ }^{204}$ Whish and Bailey, n 12, 469.

205 Ibid.; Enterprise Act 2002 s 161 \& Sched 8.

${ }^{206}$ The Competition Commission and subsequently the CMA have undertaken market investigations in a variety of sectors and with very differing results: Andrea Coscelli \& Antonia Horrocks 'Making Markets Work Well: The U.K. Market Investigation Regime' 10 Competition Policy International (2014) 24 esp at 33 - 43 (summarising the cases so investigated). None of these investigations led to the sort of broad code of conduct affecting commercial contract terms as was imposed in relation to the retail grocery sector, though, in the case of local bus services, local bus operators that manage bus stations were required to provide access to bus stations for rival operators on "fair and reasonable" and non-discriminatory terms in order to open up the bus services market to competition: the Local Bus Services Market Investigation (Access to Bus Stations) Order 2012 .
} 
(especially in being able to obtain lower prices from their suppliers) as itself a problem for competition: indeed, it saw this as beneficial to consumers as it tended to reduce prices. ${ }^{207}$ Moreover, the Competition Commission did not see the use by large retailers of below-cost selling in itself as predatory in relation to other grocery retailers, as it represented effective competition between retailers which benefits consumers by reducing the average price for a basket of products. ${ }^{208}$ However, the Competition Commission did see the practices of very large retailers in relation to their suppliers as problematic for competition, as "the transfer of excessive risks or unexpected costs by grocery retailers to their suppliers is likely to lessen suppliers' incentives to invest in new capacity, products and production processes" and "if unchecked, these practices would ultimately have a detrimental effect on consumers." ${ }^{209}$ The principal manner in which these risks or costs were transferred was "through retailers making retrospective adjustments to the terms of supply." 210 The remedy for these problems was the establishment of a Groceries Supply Code of Practice, based on an existing Supermarkets Code of Practice but amended in a number of ways. ${ }^{211}$ The Competition Commission therefore made an Order in 2009 which introduced a new Code of Practice ("the Groceries Code" or "Code") which applies to all "designated retailers", ie 10 named large retailers of groceries (as defined) and any retailer with a turnover exceeding $£ 1$ billion with respect to UK retail supply of groceries and designated by the CMA or any person carrying on the whole or a substantial part of their business. ${ }^{212}$ The 2009 Order provides that "a Designated

\footnotetext{
${ }^{207}$ Competition Commission, The supply of groceries in the UK market investigation (30 April 2008) paras $35-$ 36.

${ }^{208}$ Ibid, para 19. In addition, the Commission identified problems arising from the fact that several retailers have strong positions in local markets: paras $22-31$.

${ }^{209}$ Ibid, para 36.

${ }^{210}$ Ibid, para 37.

${ }^{211}$ Ibid, paras $46-51$.

${ }^{212}$ Competition Commission, The Groceries (Supply Chain Practices) Market Investigation Order 2009 (2009 Order), Article 4 and Sched 2. Two more retailers were added in 2018: CMA Notices of Designation for Ocado Group plc and B \& M European Value Retail S.A.
} 
Retailer must not enter into or perform any Supply Agreement ${ }^{213}$ unless [it] incorporates the Code and does not contain any provisions that are inconsistent with the Code. ${ }^{214}$ A supply agreement must be recorded in writing and the supplier must be provided, inter alia, with a written copy of the agreement "and of all terms and conditions which are intended to be incorporated, but are not fully documented, in the Supply Agreement."215

The Groceries Code itself contains 17 provisions running to nearly 2,500 words. ${ }^{216}$ Paragraph 2 Principle of fair dealing, provides:

A Retailer must at all times deal with its Suppliers fairly and lawfully. Fair and lawful dealing will be understood as requiring the Retailer to conduct its trading relationships with Suppliers in good faith, without distinction between formal or informal arrangements, without duress and in recognition of the Supplier's need for certainty as regards the risks and costs of trading, particularly in relation to production, delivery and payment issues.

To an English contract lawyer, this provides a very striking recognition of a general requirement of fair dealing in a commercial context defined, in part, by reference to good faith! The Competition Commission was particularly concerned, though, with distortions in the market resulting from retailers' practices in relation to their suppliers' risks and costs and the Code therefore controls the extent and the method by which retailers are able to vary the terms of supply, requiring that the Supply Agreement sets out "clearly and unambiguously" where and how any specific change of circumstance may allow adjustments. ${ }^{217}$

\footnotetext{
${ }^{213}$ Defined as an agreement made between a designated retailer and a supplier under which the latter supplies groceries directly to the retailer for resale in the UK: 2009 Order art 2(1)) referring to art 6)

2142009 Order, art 5(1).

${ }^{215} 2009$ Order, art 6(1) \& (2).

${ }^{216} 2009$ Order, Sched 1.

${ }^{217}$ Groceries Code, para 3.
} 
The Code further provides that a retailer must pay the supplier in accordance with their agreement and, "in any case, within a reasonable time after the supplier's invoice unless provided in the supply agreement", ${ }^{218}$ the retailer must not require a supplier to make any payment towards the retailer's marketing costs (such as artwork or packaging design, consumer or market research, the opening or refurbishment of a store etc ${ }^{219}$ ) nor payments for shrinkage (ie losses of groceries after delivery caused by their loss, theft or an accounting error), wastage, or for being a supplier (with certain exceptions). ${ }^{220}$ The retailer must not require the supplier to make any payment in respect of consumer complaints made by the retailer, unless these are justified in certain ways. ${ }^{221}$ Finally, para 16(1) governs "de-listing" by a retailer, ie ceasing to purchase or reducing the volume of purchases of groceries for resale from a particular supplier. ${ }^{222}$ It provides:

A Retailer may only De-list a Supplier for genuine commercial reasons. For the avoidance of doubt, the exercise by the Supplier of its rights under the Supply Agreement (including this Code) or the failure by a Retailer to fulfil its obligations under the Code or [the 2009] Order will not be a genuine commercial reason to Delist a Supplier.

Where a retailer does de-list, it must give the supplier reasonable notice of its decision with its reasons for doing so in writing, with the possibility of this decision being reviewed by one of the retailer's own designated senior buyer. ${ }^{223}$

The 2009 Order itself provides that a "Designated Retailer must negotiate in good faith with a Supplier to resolve any dispute arising under the Code"224 and originally

\footnotetext{
${ }^{218}$ Groceries Code, para 5.

${ }^{219}$ Groceries Code, para 6. It also controls the extent to which retailers can charge their suppliers for better positioning of their products: ibid, paras 12 and 13 .

${ }^{220}$ Ibid, paras $7-9$. The definitions of shrinkage and wastage are found in para 1(1).

${ }^{221}$ Ibid, para 15.

${ }^{222}$ Ibid, para 1(1) "De-list".

${ }^{223}$ Ibid, paras 16(2) \& 17.
} 
envisaged an ombudsman scheme for the arbitration of any disputes unresolved by the parties. ${ }^{225}$ However, the adjudication of disputes under the Code was put on a statutory basis by the Groceries Code Adjudicator Act 2013 which created the office of Groceries Code Adjudicator (GCA). ${ }^{226}$ Where a supplier refers a dispute under the Code with a designated retailer to arbitration under the 2009 Order, the Adjudicator must arbitrate the dispute or appoint another person to do so; where a retailer refers a dispute to arbitration under a supply agreement, the Adjudicator may accept appointment as the arbitrator. ${ }^{227}$ The Adjudicator has considerable powers of investigation and enforcement, the latter including recommendations as to what the retailer should do to comply with the Code, requiring the retailer to publish information relating to the investigation, and by imposing a financial penalty. ${ }^{228}$ The maximum penalty has been set at $1 \%$ of the UK turnover of the retailer. ${ }^{229}$

In 2016, the Competition and Markets Authority reported on its own work monitoring compliance with the 2009 Order (compliance with the Code is for the GCA) in relation to Groceries Supply Agreements. ${ }^{230}$ The CMA found that these agreements varied in style and content from sets of standard terms to bespoke agreements and it set out a checklist of key points to assist retailers in complying with the Order, but it did not identify any breaches of the Order. ${ }^{231}$ The GCA itself reports annually on its work, and has explained that it adopts "a modern regulatory approach, with collaboration and business relations at its core" in the interests of reducing the costs of regulation and delivering results more quickly. ${ }^{232}$ It receives

\footnotetext{
${ }^{224} 2009$ Order art 11, which also explains when a dispute arises for these purposes. 2252009 Order art 11.

${ }^{226}$ Groceries Code Adjudicator Act 2013 s 1, Sched 1. See https://www.gov.uk/government/organisations/groceries-code-adjudicator (accessed 5 December 2018)

${ }^{227}$ Groceries Code Adjudicator Act 2013 s 2.

${ }^{228}$ Ibid, ss $7-9$.

${ }^{229}$ Groceries Code Adjudicator (Permitted Maximum Financial Penalty) Order 2015 (SI 2015/722) (which provides how turnover is to be calculated for this purpose). The power to fine came into force after the only completed investigation undertaken by the GCA into Tesco plc's payment practices (26 January 2016).

${ }^{230}$ CMA, Supply Agreements under the Groceries (Supply Chain Practices) Market Investigation Order 2009, CMA's report on compliance (12 July 2016).

${ }^{231}$ Ibid paras $4-5.0$

${ }^{232}$ GCA, Groceries Code Adjudicator, Annual Report and Accounts (1 April 2017 - 31 March 2018) 11 - 12
} 
a number of complaints (in confidence) and has published lists of the issues thereby raised. ${ }^{233}$ Moreover, it has launched investigations into the practices of particular retailers when it has concerns about compliance with requirements of the Code. ${ }^{234}$

How does this system of control compare with the controls in art 442-6-I. $2^{\circ}$ of the French Commercial Code?

First, while the origins of the French provisions concerned large-scale retail distribution, the controls in art 442-6-I. $2^{\circ}$ are not so restricted, let alone being restricted to a specified set of retailers designated by reference to their market-share or turnover, as are the UK controls. ${ }^{235}$ Moreover, the processes by which the controls were put in place were very different. The UK Groceries Code resulted from a sophisticated market investigation by the Competition Commission at the request of the OFT, whereas the changes to the French Commercial Code were - if one looks at the published materials - the result primarily of political and legal argument, with a relatively restricted economic analysis. ${ }^{236}$

Secondly, the most important differences lie in what the two regimes replaced and in their treatment of prices paid to suppliers. The French legislative changes of 2008 sought to allow retailers and their suppliers to enjoy the benefits of free negotiation of prices and terms, instead of the earlier controls based on the "tarification" of prices, the prohibition of belowcost selling by retailers and the resulting abusive back margins charged for "commercial services" by retailers. ${ }^{237}$ The background to the UK Groceries Code was the legal recognition in principle of freedom to negotiate prices and terms, an acceptance of the use of

\footnotetext{
${ }^{233}$ Ibid, $31-49$.

${ }^{234}$ Ibid, 13 and 27 - 28, noting its investigation into possible breaches of the Code by the Co-operative Group Ltd. in relation to De-listing and benchmarking and depot quality control charges. See also its investigation into the payment practices of Tesco plc, above, n 229.

235 Above, p 00.

${ }^{236}$ See, notably, the main report which preceded the $l o i$ of 2008 , the Report Hagelsteen. Of course, more sophisticated market analysis may have been carried out internally by the Ministry or by the French competition regulator, the Direction Générale de la Concurrence, de la Consommation et de la Répression des Fraudes (DGCCRF).

${ }^{237}$ Above, p 00.
} 
below-cost selling and - most surprising of all from a French point of view - an acceptance of the greater bargaining power of retailers over their suppliers on the ground that it is good for consumers. ${ }^{238}$ What the French and English regimes have in common, though, is the idea that free negotiation should be subject to the requirements of fairness, including as to payment terms and the breaking-off the commercial relationship (de-listing). ${ }^{239}$ A key difference is that the French scheme allows a court to assess not merely the general terms on which a supply contract is made, but also the level of the prices charged, ${ }^{240}$ whereas the UK Groceries Code of Practice does not subject to review the level of the cost of groceries, even though it prohibits certain charges by retailers which could well be seen as disguised ways of reducing their supply costs (rather like the French "back charges"). ${ }^{241}$

Thirdly, in terms of enforcement, the UK Groceries Code as policed by its Adjudicator seeks to establish fairness in the conduct of very large retailers by responding to supplier complaints and then working together with the retailers themselves. While investigations into breaches of the Code (which can result in the imposition of penalties) have taken place, they are rare. By contrast, under the French regime, the commission of unfair commercial practices by retailers (and others) attracts their "responsibility" and this may be invoked both by the public regulator in enforcement proceedings and, much more commonly, by the other traders thereby affected. ${ }^{242}$

\section{Conclusion}

\footnotetext{
${ }^{238}$ Above, p 00.

${ }^{239}$ These issues are governed specially by art. $442-6-\mathrm{I} .1^{\circ}, 4^{\circ}-5^{\circ}, 7^{\circ} \& 8^{\circ} \mathrm{C}$ com.

${ }^{240}$ Above, p 00.

241 Above, p 00.

${ }^{242}$ Above, p 00 and n 86.
} 
The contract laws controlling the fairness of non-consumer contract terms in French and English law have recently grown much further apart. French law has introduced two new broad sets of controls, each with their own background and concerns. The controls on commercial contracts in the Commercial Code have a background in the regulation of prices and contract terms and in particular concerns about unfair competition in the large-scale retail sector; controls were needed in the interests of other traders rather than of consumers, though it was realised that the earlier regime had in fact encouraged inflated prices for consumers. ${ }^{243}$ Ironically, liberalisation which introduced the free negotiation of prices and contract terms led to new judicial controls on all the terms of a contract including those setting the level of the prices in all commercial contracts. ${ }^{244}$ By contrast, the new general controls on the terms of contrats d'adhésion in the Civil Code has deep roots in French civil law's distrust of contracts in which the parties' wills are not fully engaged and in the doctrinal concept of a contrat d'adhésion itself, but the criterion of "negotiability" ultimately used to define such a contract does suggest that where terms are not negotiable (as opposed to not negotiated), the normal play of the market is not possible, a form of market failure.

The odd feature remains, however, that in French law the prices and definition of the subject-matter of commercial contracts may be reviewed for their "significant imbalance" provided only that one party "subjected" their "commercial partner" to them, whereas the prices and subject-matter of civil or consumer contracts are generally immune from review. ${ }^{245}$ It remains to be seen whether this will be corrected by further amendment of the Commercial Code or even by judicial interpretation so as to restrict its sphere of application to its controls of unfair terms to intended context of contracts made in the large-scale retail

\footnotetext{
243 Above, p 00.

244 Above, p 00.

${ }^{245}$ Above, pp 00 and 00.
} 
sector. $^{246}$ More broadly, the provisions in both the Civil Code and the Commercial Code affecting the validity of contract terms reflect fundamental values adopted by French law expressed: the private law principles of freedom of contract and the binding force of contract and the market law principle of freedom of commerce all require qualification on the basis of fairness and justice. Contrary to the apparent sense of Fouillé's famous aphorism, ${ }^{247}$ fairness is no longer seen as what one agrees in the contract, it is an independent standard by which the contract is to be judged. This may well reflect the special and more "social model" of contract law advocated by some French scholars, but the broad scope of the review of contract terms significantly undermines its claim of the 2016 reforms to make French law more attractive as a law of choice for international commercial contracts. ${ }^{248}$

By contrast, general English law still reflects the liberal values of its nineteenth century origins, buttressed by a keen sense that this promotes the fundamental role of contracts as a market mechanism. Freedom of contract remains a potent common law principle, whereas broad qualifying principles such as a requirement of good faith, a general law of unfair competition or a general theory of the abuse of rights remain rejected as principles, even if particular examples of each can be identified either in so many words or in terms of functional equivalence. In the case of the control of the fairness of the terms of contracts, all this argues against any general power of review unless a particular justification is established: in the type of economic relationship (consumer contracts), in the type of contract term (exemption clauses or penalty clauses) or owing to the particular type of contract or its market context. As regards the latter, where a market failure is established in

\footnotetext{
${ }^{246}$ As advocated by Deshayes, Genicon and Laithier, n 140, $344-345$.

247 Above, p 00.

${ }^{248}$ Rapport au Président at 3. Art 1171 is clearly mandatory in national law (Rapport au Président, 11, ie its application cannot be excluded by contract) and it is not clear that French courts would allow the choice of a foreign law to avoid the control in art 1171, which could be treated as an "overriding mandatory provision" within the meaning of Regulation 593/2008 on the law applicable to contractual obligations ("Rome I") [2008] O.J. L177/6 art 9. The Tribunal de commerce of Paris has held that art 442-6.I. $2^{\circ} \mathrm{C}$ com falls within art 9 of Rome I: Trib com 7 mai 2015, Expedia Inc no 2015000040.
} 
a particular commercial sector, the UK has proved willing to adopt dedicated control measures to correct it, including the provision for complaints to be made of unfair trade practices by other traders. And, where it is, fairness and good faith may be given a central role. 